\title{
Sistem Informasi Absensi Berbasis Website Menggunakan API WhatsApp dengan Metodologi Incremental (Studi Kasus: SMP Negeri 29 Pekanbaru)
}

\author{
Sendy Aprilia \\ Teknik Informatika, Politeknik Caltex Riau \\ sendy16ti@mahasiswa.pcr.ac.id
}

\begin{tabular}{l}
\hline Article Info \\
\hline Article history: \\
Received 2020-03-15 \\
Revised 2020-04-19 \\
Accepted 2020-04-22 \\
\hline
\end{tabular}

Keyword:

Absence,

Incremental,

Gap Analysis,

API WhatsApp.

\begin{abstract}
The development of technology has become more sophisticated and easily accesible, so that school inspectors are required to be creative and able to master technology in the world of education. Junior High School number 29 Pekanbaru is one of the school agencies that is facing technological problems in processing attendance data, which is still conventional using printed paper for each class to attend student attendance. In addition using gap analysis methodology is needed to find out what needs to be improved. The result of gap analysis was found that user felt the completeness of attendance data and absent data storage did not work optimally because it took a long time and the user also needed direct integration of parents about student absence in order to avoid bad behavior that occurred at school. In the end the school agency needs to improve the quality of the attendance system that is more efficient, effective and fast. After getting these problems, a system will be built to overcome the problems that occur at the school. This system will be built using the PHP programming language and MySQL as a database. For system design utilizing an incremental methodology. The incremental methodology is perfect for developers who have high turnover so that it can be done in parallel without waiting for the other stages to be completed. Data needed in this system is data relating to students, teachers at school and parents of students at home. The expected results of this system are every student absence will be sent via WhatsApp message to parents, can help teachers in making attendance and facilitate parents in monitoring student attendance at school. Testing on this system uses the gap analysis method and the test result is changes in needs that must be corrected to needs that are in accordance with what is desired is the movement of needs in quadrant 1 to quadrant 2. This shows the attendance system that is designed in accordance with the wishes of the user.
\end{abstract}

\section{Pendahuluan}

Seiring dengan perkembangan teknologi informasi yang semakin pesat, masih banyak sekali sarana dan prasarana sekolah yang belum memanfaatkan teknologi informasi dengan baik. Padahal dengan adanya teknologi informasi dapat mengubah sistem yang awalnya semua dilakukan secara manual menjadi terkomputerisasi seperti halnya absensi siswa. Kegiatan absensi siswa ini sudah menjadi rutinitas yang dilakukan setiap hari selama kegiatan belajar mengajar untuk mengetahui siswa yang berhalangan hadir dengan keterangan sakit, izin dan alfa. Selama ini absensi siswa di SMP Negeri 29 Pekanbaru masih bekerja secara manual. Pasalnya sering terjadi masalah-masalah yang selalu dihadapi oleh guru dan orang tua siswa. Setiap siswa yang berhalangan hadir maupun siswa yang sudah hadir kemudian siswa meninggalkan sekolah di waktu pembelajaran tanpa sepengetahuan guru meresahkan pihak sekolah karena orang 
tua beranggapan bahwa anaknya sekolah dengan benar, padahal mereka tidak sampai ke sekolah melainkan bermainmain. Sebagai sanksi atas masalah yang terjadi, guru memberikan Surat Panggilan untuk orang tua, tetapi terkadang tidak disampaikan kepada orang tua, karena takut ketahuan atas perilaku buruknya di sekolah. Selain itu, melalui pendekatan gap analysis, ditemukan bahwa pihak sekolah merasa kelengkapan data absensi serta penyimpanan data absensi belum bekerja secara maksimal karena membutuhkan waktu yang cukup lama serta pihak sekolah membutuhkan integrasi langsung kepada orang tua mengenai ketidakhadiran siswa di sekolah.

Berdasarkan permasalahan tersebut dibangunlah sebuah sistem informasi absensi menggunakan bahasa pemprograman PHP dan MySQL sebagai database. Pengembangan sistem menggunakan metodologi Incremental. Metode ini dinilai sesuai karena memberikan progress yang mengarah pada fungsionalitas pengguna. Pengerjaan sistem informasi ini dilakukan secara bertahap melalui setiap increment dilakukan analisis di awal dan uji di akhir untuk mendapatkan fungsi-fungsi yang sesuai dengan permintaan pengguna [1]. Metode Incremental cocok dan mampu mengakomodasi perubahan secara fleksibel serta cocok untuk pengembang yang memiliki turnover tinggi [2]. Setiap ketidakhadiran absensi siswa akan dikirimkan melalui pesan WhatsApp. Pemberitahuan ini menggunakan API WhatsApp karena zaman sekarang ini banyak yang menggunakan WhatsApp sebagi salah satu media sosial saat ini banyak yang menggunakan untuk kepentingan bersosialisasi maupun sebagai penyampaian pesan baik oleh individu maupun berkelompok [3]. Namun tidak hanya sebagai penyampaian informasi pada ruang lingkup yang kecil saja, tetapi dapat dimanfaatkan pada ruang lingkup yang besar seperti instansi sekolah maupun instansi lainnya sebagai pemanfaatan notifikasi yang lebih intens untuk memberikan dan menerima informasi. Pemanfaatan WhatsApp ini terintegrasi ke dalam sistem sehingga transaksi data semakin irit dan bandwidth yang digunakan juga lebih sedikit [4].

Sistem informasi absensi menggunakan API Whatsapp diharapkan dapat membantu guru SMP Negeri 29 dalam melakukan absensi siswa, memudahkan tata usaha dalam melakukan penyimpanan serta pengolahan data absensi dan memudahkan orang tua dalam memantau ketidakhadiran siswa di sekolah. Kemudian, ketika sistem telah digunakan, maka akan dilakukan pendekatan metode gap analysis kembali untuk melihat perbandingan kondisi sebelum dan sesudah sistem dibuat apakah sesuai atau tidak dengan kebutuhan instansi sekolah di SMP Negeri 29 Pekanbaru.

Penelitian pada sebuah sistem absensi pernah dilakukan untuk mendata absensi siswa dimana diberikan hak akses kepada admin dan guru piket, namun pendataan absensi ini dilakukan penginputan secara manual karena belum adanya informasi mengenai data guru dan data siswa sehingga tidak bisa memanfaatkan data yang ada. Kesimpulan yang didapatkan dari penelitian ini adalah sistem ini hanya berfokus pada presensi siswa saja [5]. Penelitian selanjutnya melakukan perancangan sistem absensi yang memiliki fitur untuk memberikan informasi-informasi yang terkait untuk guru, tata usaha dan bagian konseling. Penelitian ini menghasilkan proses pendataan absensi berupa rekapitulasi secara periodik [6]. Penelitian selanjutnya melakukan perancangan sistem absensi yang memiliki fitur untuk memberikan informasi-informasi yang terkait seperti data siswa per kelas, data guru, data ruang kelas, data mata pelajaran serta data pengolahan nilai. Penelitian ini tidak hanya menghasilkan pendataan absensi tetapi juga nilai siswa [7], rekap honor [8]. Penelitian selanjutnya bertujuan untuk merancang dan membangun sebuah sistem rekapitulasi hasil pembelajaran dan absensi siswa. Pada penilitian ini lebih kompleks dan tidak hanya merekap absensi tetapi juga hasil pembelajaran siswa di sekolah. Sistem ini juga dilengkapi notifikasi kepada pengguna (orang tua) melalui SMS Gateway [9] [10].

\section{Metode Penelitian}

\section{A. Gap Analysis}

Metode gap analysis merupakan metode yang digunakan untuk mengevaluasi bisnis dengan membandingkan kinerja perusahaan saat ini dengan kinerja yang sudah ditargetkan sebelumnya serta menentukan langkah-langkah apa yang perlu dilakukan untuk mengurangi kesenjangan tersebut dan mencapai kondisi yang diinginkan di masa depan[11]. Untuk mempermudah dalam mengetahui hal apa saja yang perlu dilakukan sampai pada tujuan adalah melalui bagan matriks importance \& perfomance untuk mengetahui gambaran tingkat kepentingan dan tingkat kinerja menurut pengguna yang dihubungkan dengan variabel yang dirasakan oleh pengguna [12]. Bagan Matriks Importance \& Performance berikut.

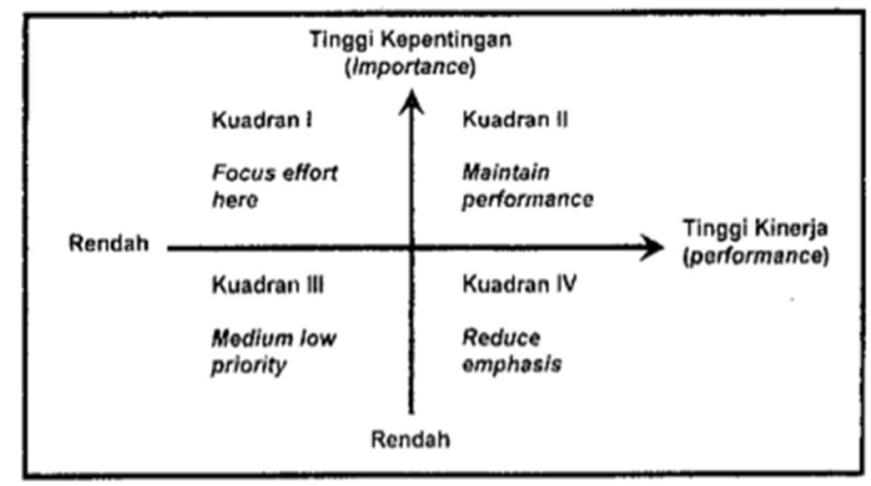

Gambar 1. Bagan Matriks Importance \& Performance

Untuk mendapatkan informasi dan segala kebutuhan data sistem yang akan dirancang, pertama-tama dilakukan pengumpulan data dengan cara pembagian kuesioner kepada 20 responden kepada pihak sekolah SMP Negeri 29 Pekanbaru untuk melihat kondisi realistis sekarang. Kemudian hasil data kuesioner tersebut akan ditentukan melalui bagan matriks importance \& perfomance dan yang 
akan digunakan untuk proses perancangan sistem. Dalam proses pembagian kuesioner akan diajukan 10 pernyataan yang telah disusun sedemikian rupa oleh perancang. Pernyataan ini didapatkan dari hasil penelitian perancang melalui wawancara kepada tata usaha dan guru. Pernyataan yang dijawab harus berpaku pada bobot penilaian tingkat kinerja dan tingkat kepentingan. Format kriteria penilaian persepsi pengguna tentang kriteria kinerja dapat dilihat pada Tabel I dan kriteria kepentingan dapat dilihat pada Tabel II.

TABEL I

Bobot Kriteria Penilaian TingKat KinerJa

\begin{tabular}{|c|c|}
\hline \multicolumn{2}{|c|}{$\begin{array}{c}\text { Kriteria Penilaian Persepsi Pengguna } \\
\text { (Tingkat Kinerja) }\end{array}$} \\
\hline Keterangan & Bobot \\
\hline Sangat Puas & 4 \\
\hline Puas & 3 \\
\hline Tidak Puas & 2 \\
\hline Sangat Tidak Puas & 1 \\
\hline
\end{tabular}

TABEL III

Bobot Kriteria Penilaian TingKat KePentingan

\begin{tabular}{|l|c|}
\hline \multicolumn{2}{|c|}{$\begin{array}{c}\text { Kriteria Penilaian Persepsi Pengguna } \\
\text { (Tingkat Kepentingan) }\end{array}$} \\
\hline \multicolumn{1}{|c|}{ Keterangan } & Bobot \\
\hline Sangat Penting & 4 \\
\hline Penting & 3 \\
\hline Tidak Penting & 2 \\
\hline Sangat Tidak Penting & 1 \\
\hline
\end{tabular}

Daftar pernyataan untuk kriteria kinerja dan kepentingan dapat dilihat pada Tabel III. Daftar pernyataan Kriteria Kinerja dan Kepentingan berikut.

TABEL IIIII

DAFTAR PERNYATAAN KRITERIA KINERJA

\begin{tabular}{|c|l|c|c|c|c|}
\hline \multirow{2}{*}{ No } & \multicolumn{1}{|c|}{ Pernyataan } & \multicolumn{4}{|c|}{ Kinerja Sekarang } \\
\cline { 3 - 6 } & STP & TP & P & SP \\
\hline 1 & Kelengkapan data siswa & 7 & 8 & 5 & 0 \\
\hline 2 & Kelengkapan data guru & 6 & 10 & 4 & 0 \\
\hline 3 & Kelengkapan data kelas & 9 & 8 & 3 & 0 \\
\hline 4 & $\begin{array}{l}\text { Kelengkapan data mata } \\
\text { pelajaran }\end{array}$ & 8 & 8 & 4 & 0 \\
\hline 5 & $\begin{array}{l}\text { Kelengkapan data absensi } \\
\text { siswa }\end{array}$ & 9 & 11 & 0 & 0 \\
\hline 6 & $\begin{array}{l}\text { Waktu pengelolaan data } \\
\text { absensi }\end{array}$ & 16 & 4 & 0 & 0 \\
\hline 7 & $\begin{array}{l}\text { Tatap muka terhadap } \\
\text { siswa ketika absensi }\end{array}$ & 10 & 5 & 5 & 0 \\
\hline
\end{tabular}

\begin{tabular}{|c|l|c|c|c|c|}
\hline 8 & Waktu absensi & 15 & 5 & 0 & 0 \\
\hline 9 & $\begin{array}{l}\text { Penyimpanan data absensi } \\
\text { siswa }\end{array}$ & 10 & 6 & 4 & 0 \\
\hline 10 & $\begin{array}{l}\text { Integrasi langsung kepada } \\
\text { orang tua }\end{array}$ & 13 & 4 & 3 & 0 \\
\hline
\end{tabular}

TABEL IVV

Daftar PernyataAn Kriteria KePEntingan

\begin{tabular}{|c|l|c|c|c|c|}
\hline \multirow{2}{*}{ No } & \multicolumn{1}{|c|}{ Pernyataan } & \multicolumn{4}{|c|}{ Kepentingan } \\
\cline { 3 - 6 } & STP & TP & P & SP \\
\hline 1 & Kelengkapan data siswa & 0 & 0 & 0 & 20 \\
\hline 2 & Kelengkapan data guru & 0 & 0 & 0 & 20 \\
\hline 3 & Kelengkapan data kelas & 0 & 0 & 5 & 15 \\
\hline 4 & $\begin{array}{l}\text { Kelengkapan data mata } \\
\text { pelajaran }\end{array}$ & 0 & 0 & 7 & 13 \\
\hline 5 & $\begin{array}{l}\text { Kelengkapan data absensi } \\
\text { siswa }\end{array}$ & 0 & 0 & 3 & 17 \\
\hline 6 & $\begin{array}{l}\text { Waktu pengelolaan data } \\
\text { absensi }\end{array}$ & 0 & 0 & 5 & 15 \\
\hline 7 & $\begin{array}{l}\text { Tatap muka terhadap } \\
\text { siswa ketika absensi }\end{array}$ & 0 & 0 & 12 & 8 \\
\hline 8 & Waktu absensi & 0 & 0 & 2 & 18 \\
\hline 9 & $\begin{array}{l}\text { Penyimpanan data absensi } \\
\text { siswa }\end{array}$ & 0 & 0 & 8 & 12 \\
\hline 10 & $\begin{array}{l}\text { Integrasi langsung kepada } \\
\text { orang tua }\end{array}$ & 0 & 0 & 0 & 20 \\
\hline
\end{tabular}

Setelah mendapatkan jawaban dari responden, kemudian akan dilakukan perhitungan rata-rata dengan menggunakan rumus perhitungan metode gap analysis berikut.

$$
\overline{X i}=\frac{\sum_{i=1}^{k}}{n} \quad \overline{Y i}=\frac{\sum_{i=1}^{k}}{n}
$$

Dimana; $\overline{X i}=$ bobot rata-rata tingkat penilaian kinerja atribut/pernyataan ke-i.

$\overline{Y i}=$ bobot rata-rata tingkat penilaian kinerja atribut/pernyataan ke-i

$\mathrm{n}=$ jumlah responden

Hasil perhitungan rata-rata kinerja dan kepentingan menggunakan rumus perhitungan metode gap analysis di atas dapat dilihat pada Tabel V.

TABEL V

Perbandingan Rata-RATA KinERJa DAN KePEnTINGAN

\begin{tabular}{|c|l|c|c|}
\hline No & Pernyataan & $\begin{array}{c}\text { Rata-rata } \\
\text { Kinerja }\end{array}$ & $\begin{array}{c}\text { Rata-rata } \\
\text { Kepentingan }\end{array}$ \\
\hline 1 & Kelengkapan data siswa & 1.55 & 4 \\
\hline 2 & Kelengkapan data guru & 1.9 & 4 \\
\hline 3 & Kelengkapan data kelas & 1.7 & 3.75 \\
\hline
\end{tabular}




\begin{tabular}{|c|l|c|c|}
\hline 4 & $\begin{array}{l}\text { Kelengkapan data mata } \\
\text { pelajaran }\end{array}$ & 1.8 & 3.65 \\
\hline 5 & $\begin{array}{l}\text { Kelengkapan data } \\
\text { absensi siswa }\end{array}$ & 1.55 & 3.85 \\
\hline 6 & $\begin{array}{l}\text { Waktu pengelolaan data } \\
\text { absensi }\end{array}$ & 1.2 & 3.75 \\
\hline 7 & $\begin{array}{l}\text { Tatap muka terhadap } \\
\text { siswa ketika absensi }\end{array}$ & 1.75 & 3.4 \\
\hline 8 & Waktu absensi & 1.35 & 3.9 \\
\hline 9 & $\begin{array}{l}\text { Penyimpanan data } \\
\text { absensi siswa }\end{array}$ & 1.7 & 3.6 \\
\hline 10 & $\begin{array}{l}\text { Integrasi langsung } \\
\text { kepada orang tua }\end{array}$ & 1.5 & 4 \\
\hline
\end{tabular}

Setelah mendapatkan rata-rata kinerja dan rata-rata kepentingan didapatkan lagi hasil yaitu sebuah matriks yang menunjukkan tingkat kebutuhan perbaikan pada kuadrankuadran tertentu. Bagan Matriks Perfomance \& Importance untuk Identifikasi Kebutuhan Sebelum Penggunaan Sistem dapat dilihat pada Gambar 2 berikut.

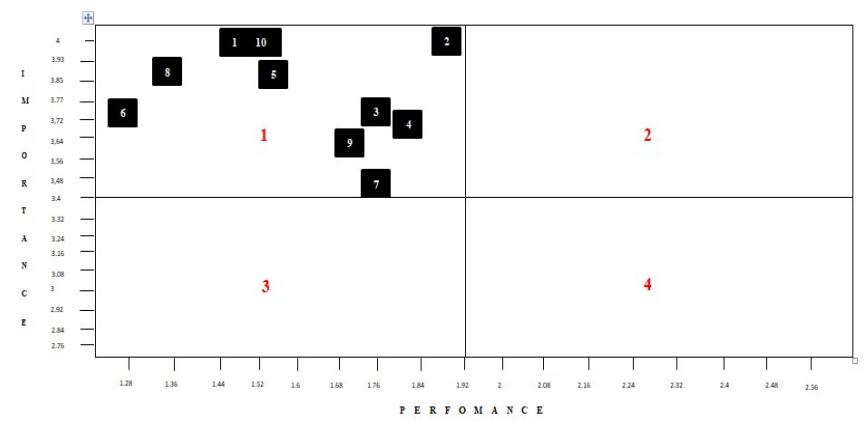

Gambar 2. Bagan Matriks Sebelum Penggunaan Sistem

Berdasarkan hasil analisa dari bagan matriks di atas, 10 pernyataan tersebut masuk ke dalam kuadran I. Kuadran I adalah kuadran yang diperlukan langkah-langkah untuk perbaikan sistem absensi yang manual. Matriks ini akan menjadi tolak ukur dalam pengambilan keputusan untuk melakukan penerapan fitur-fitur pada sistem absensi agar sistem dapat berjalan sesuai dengan keinginan pengguna. Setelah memperoleh apa saja fitur-fitur yang ada pada sistem, selanjutnya langkah-langkah fitur tersebut akan dikembangkan ke dalam metode incremental.

\section{B. Incremental}

Metode incremental merupakan pilihan alternatif dalam cara kerja pengembangan sistem absensi yang diaplikasikan dalam model linear secara berurutan dan setiap linear per increment akan menghasilkan fitur-fitur dari sistem. Dari fitur-fitur sistem yang akan dikembangkan, fitur-fitur tersebut dibagi menjadi 2 perancangan incremental yaitu perancangan incremental sisi tata usaha dan perancangan incremental sisi guru. Pada sisi tata usaha terbagi menjadi 8 increment sedangkan pada sisi guru hanya terdapat 1 increment saja. Tahap incremental pada sisi tata usaha dapat dilihat pada Gambar 3.

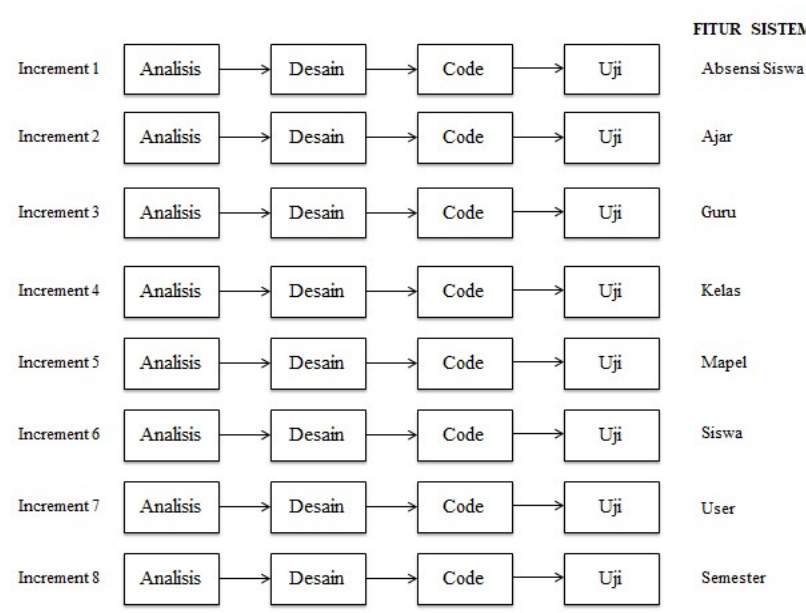

Gambar 3.Tahap Incremental pada Sisi Tata Usaha

Tahap incremental pada sisi guru dapat dilihat pada Gambar 4.

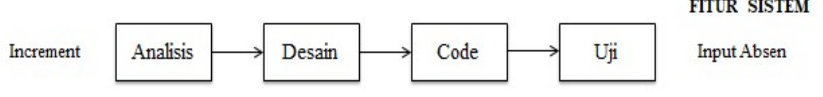

Gambar 4. Tahap Incremental pada Sisi Guru

\section{Perancangan Sistem}

Perancangan sistem menggunakan metode Incremental. Tahapan metode Incremental ini dimulai dari tahap yang pertama yaitu analysis. Di tahap ini diperoleh analisis kebutuhan untuk increment kedua sisi pengguna melalui hasil dari kedua proses, yaitu hasil wawancara dan gap analysis. Tahap kedua yaitu desain, dimana akan dilakukan perancangan arsitektur sistem dan pengolahan API WhatsApp. Arsitektur sistem dapat dilihat pada Gambar 5 berikut.

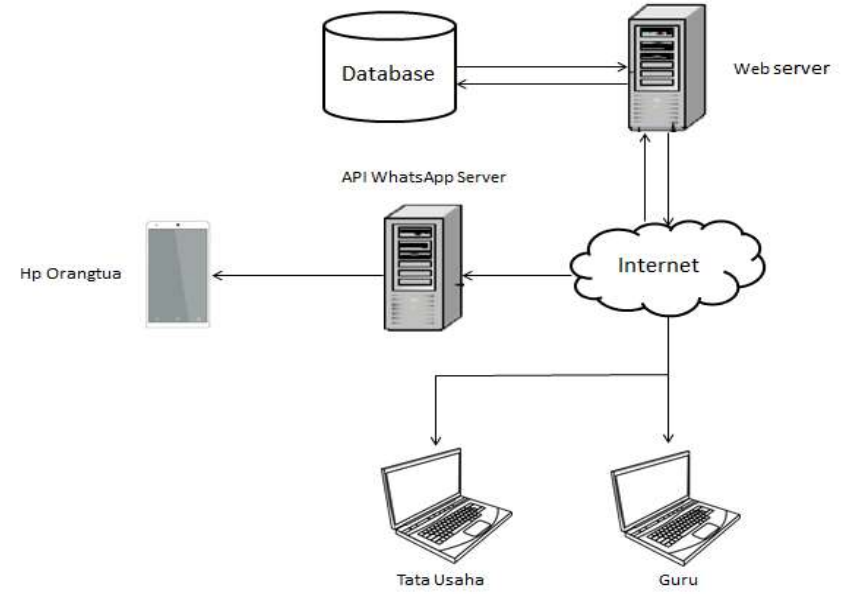

Gambar 5. Arsitektur Sistem

Pada Gambar 5, terdapat dua aktor yang memiliki hak akses dalam menjalankan sistem, yaitu tata usaha dan guru. 
Aktor tersebut mengakses sistem melalui web browser yang terhubung ke sebuah komputer server. Server menerima request dari sistem pengguna dan akan memberikan response. Data-data yang berhubungan dengan sistem, akan disimpan pada sebuah database, jika proses penginputan dengan kondisi tertentu sudah selesai, maka otomatis API WhatsApp akan mengirim informasi ketidakhadiran siswa ke smartphone orang tua melalui media sosial WhatsApp.

Pengolahan API WhatsApp dapat digunakan dengan cara mendaftarkan nomor hp orang tua dan kemudian akan mendapatkan API key sesuai dengan nomor yang telah didaftarkan. API WhatsApp memiliki database yang dapat diakses secara online untuk melihat daftar pesan yang telah dikirimkan. Tahap ketiga yaitu code, pada tahapan kode program sistem ini menggunakan bahasa pemograman $P H P$, MySQL sebagai database, dan sublime text 3 sebagai aplikasi penunjang pembangunan sistem. Tahap terakhir yaitu uji, pengujian ini dilakukan diuji dengan Blackbox Testing untuk menguji sistem secara fungsional, User Acceptance Testing dan Gap Analysis untuk mengetahui hasil sebelum dan sesudah implementasi sistem, apakah sesuai dengan harapan pengguna.

\section{Hasil dan Pembahasan}

\section{A. Hasil Pengembangan Program}

Setelah dilakukan perancangan, hasil pengembangan program dapat dilihat pada gambar berikut.

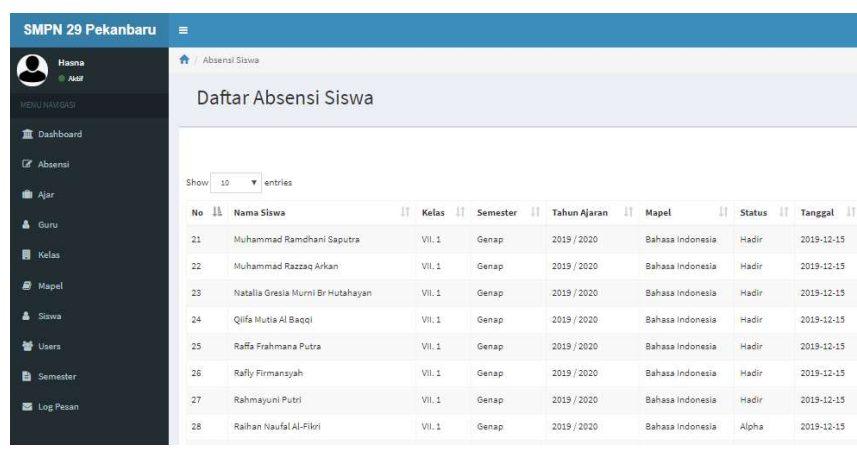

Gambar 6. Menu Kelola Absensi Siswa Sisi Tata Usaha

Gambar 7 menjelaskan bahwa halaman absensi siswa di dapatkan ketika guru menginputkan absensi terbaru siswa. Ketika tata usaha menekan tombol terima pada notifikasi data absensi siswa, maka data tersebut akan otomatis tersimpan di database. Ketika tata usaha ingin mencari data tersebut, maka lakukan eksekusi program untuk melihat data absensi siswa.

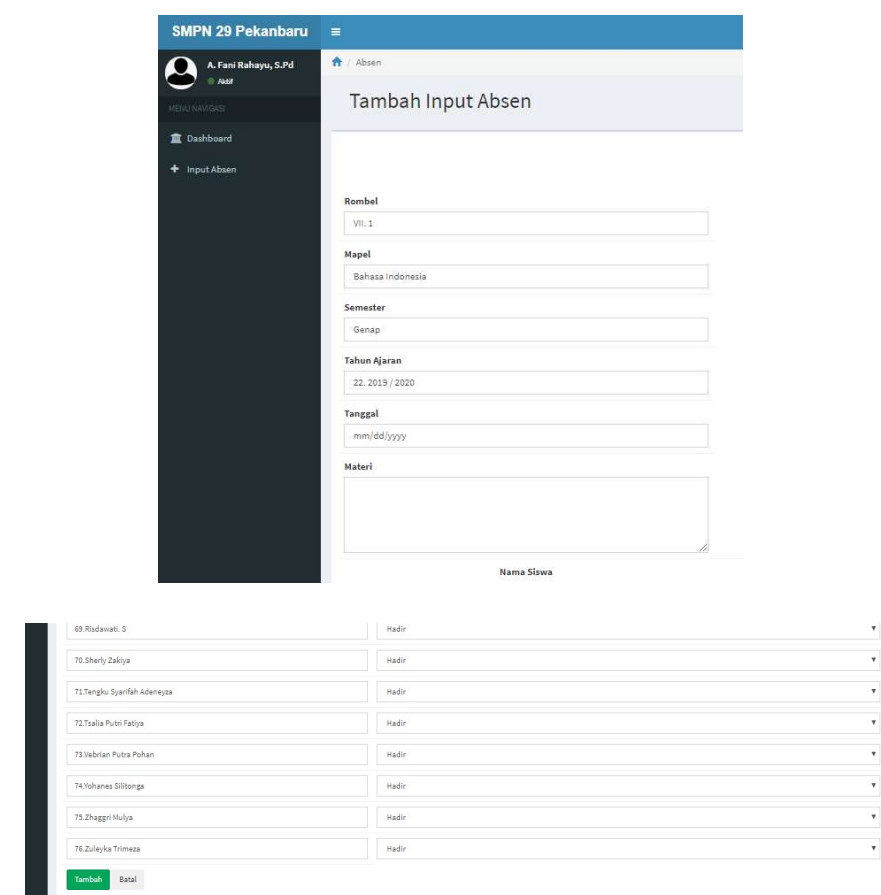

Gambar 7. Menu Input Absen pada Sisi Guru

Pada halaman ini merupakan hak akses yang hanya diberikan kepada guru. Guru dapat melakukan penambahan data absen, edit dan lihat data ajar sesuai dengan kelas dan siswa yang diajar. Ketika penginputan data absensi siswa selesai, guru akan diarahkan untuk menekan tombol tambah, artinya data absensi tersebut akan disimpan dan dikirimkan ke tata usaha dalam bentuk notifikasi sistem.

\section{B. Implementasi API WhatsApp}

Implementasi API WhatsApp terjadi ketika guru menginputkan absensi siswa terbaru, secara otomatis tata usaha akan menerima notifikasi sistem berisikan data absensi terbaru hasil penginputan guru. Notifikasi absen terbaru ditunjukkan sebagai berikut.

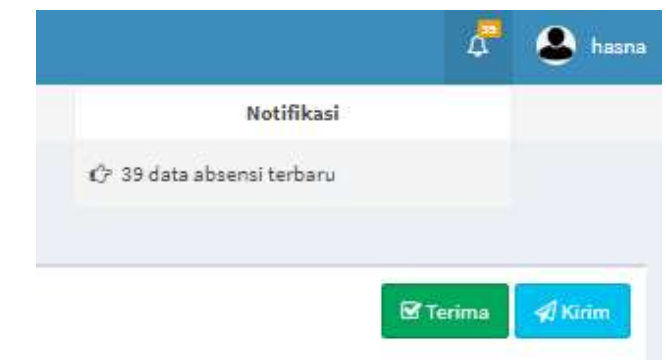

Gambar 8. Notifikasi Absen Terbaru pada Sisi Tata Usaha

Kemudian, tata usaha akan menekan tombol kirim ketika notifikasi telah dibaca. Secara otomatis sistem akan mencari data ketidakhadiran siswa dan mengirimkannya ke nomor WhatsApp orang tua. Orang tua siswa akan menerima pesan WhatsApp berisikan detail pesan mengenai informasi ketidakhadiran siswa. Pesan tersebut dapat dilihat pada Gambar 9. Detail Pesan WhatsApp berikut. 


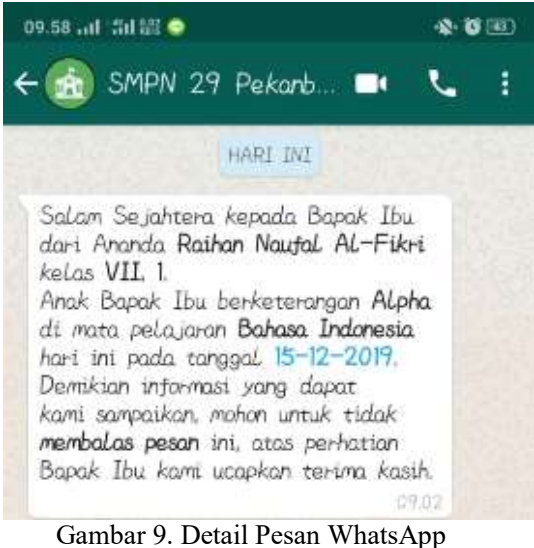

Selanjutnya, pengiriman pesan yang telah berhasil dikirimkan ke WhatsApp orang tua akan tersimpan ke dalam log pesan tata usaha dengan detail nomor penerima, tanggal, isi pesan serta status pengiriman. $\log$ pesan tersebut dapat dilihat pada Gambar 11. Log Pesan berikut.

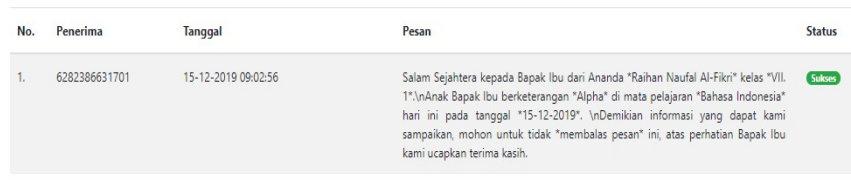

Gambar 10. Log Pesan

\section{Hasil Pengujian}

\section{1) Blackbox Testing}

Pengujian Blackbox ini adalah metode pengujian yang hanya berfokus terhadap kebutuhan fungsional sistem [13]. Pengujian lebih ditujukan pada desain sistem sesuai standar dan reaksi sistem untuk memastikan fungsionalitasnya berfungsi dengan benar. Maka diperolehlah hasil bahwa setiap fungsi yang ada pada sistem absensi ini berjalan benar dan sesuai dengan harapan.

\section{2) Gap Analysis}

Pengujian Gap Analysis dilakukan kembali untuk membandingkan hasil sistem sebelum dan sesudah menggunakan sistem informasi absensi SMP Negeri 29 Pekanbaru. Pengujian gap analysis ini dilakukan dengan menyebarkan kembali kuesioner yang pernah disebarkan sebelum implementasi sistem sebanyak 20 responden (tata usaha dan guru). Berdasarkan rekapitulasi perhitungan kuesioner, didapatkan hasil bahwa terdapat perpindahan kuadran antara penelitan gap analysis sebelumnya dan sekarang. Perubahan matriks tersebut dapat terlihat pada Gambar 11 berikut.

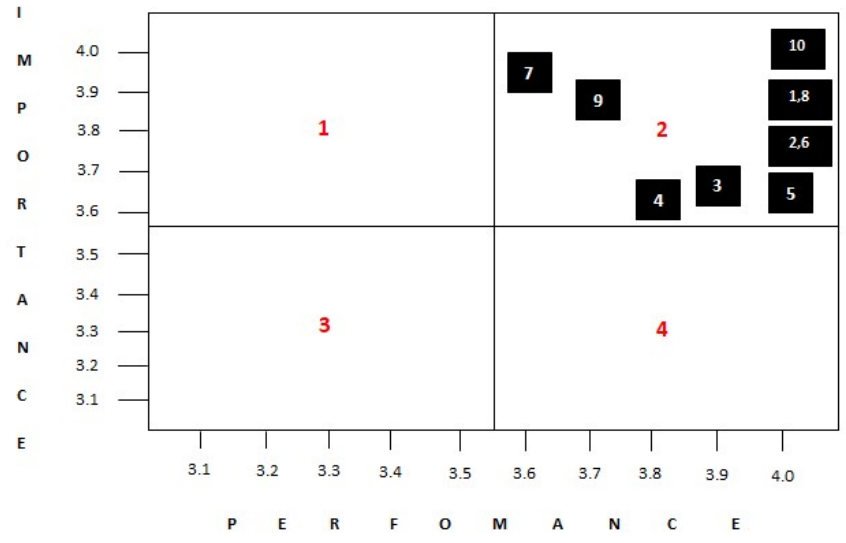

Gambar 11. Bagan Matriks Importance \& Perfomance Sesudah Penggunaan Sistem

\section{3) User Acceptance Testing}

Pengujian UAT menggunakan media kuesioner yang dilakukan pada pihak pengelola sistem yaitu tata usaha dan guru-guru SMP Negeri 29 Pekanbaru sebanyak 20 responden. Dimana akan terdapat 6 butir uji pertanyaan yang akan dijawab.

Hasil yang diperolah adalah kedua responden sangat setuju bahwa sistem absensi ini sangat membantu dalam melakukan absensi siswa secara online dan memudahkan dalam menyimpan data absensi siswa, serta memudahkan pihak sekolah untuk berintegrasi dengan orang tua dalam memantau perkembangan absensi siswa di sekolah. Kedua responden juga sangat setuju bahwa sistem absensi ini telah layak untuk diimpelemtasikan pada sistem informasi absensi SMP Negeri 29 Pekanbaru.

Selanjutnya dilakukan pengujian $U A T$ kepada pihak orang tua siswa SMP Negeri 29 Pekanbaru sebanyak 20 responden yang akan menjawab 3 butir uji pertanyaan dimana hasil yang diperoleh adalah orang tua siswa sangat setuju bahwa sistem ini memudahkan dalam mendapatkan informasi ketidakhadiran siswa. Detail informasi yang di dapatkan sangat mudah dipahami. Orang tua juga sangat setuju bahwa sistem ini sangat membantu dalam memantau ketidakhadiran siswa di sekolah.

\section{KESIMPULAN}

Setiap ketidakhadiran siswa dikirim melalui pesan WhatsApp kepada orang tua, dapat membantu guru dalam membuat kehadiran dan memfasilitasi orang tua dalam memantau kehadiran siswa di sekolah. Pengujian pada sistem ini menggunakan metode analisis kesenjangan dan hasil pengujian adalah perubahan dalam kebutuhan yang harus diperbaiki dengan kebutuhan yang sesuai dengan apa yang diinginkan adalah pergerakan kebutuhan di kuadran 1 ke kuadran 2. Ini menunjukkan sistem absensi yang ada dirancang sesuai dengan keinginan pengguna.

Adapun kesimpulan yang dapat diambil dari sistem informasi absensi ini adalah memberikan kemudahan kepada guru untuk melakukan absensi siswa, membantu tata usaha sekolah dalam penyimpanan serta pengolahan data absensi 
siswa secara mudah dan memberikan kemudahan kepada orang tua siswa dalam memonitoring ketidakhadiran siswa di sekolah.

Beberapa hal yang dapat dilakukan untuk penelitian lebih lanjut berikutnya adalah sebaiknya dilakukan sistem absensi dikembangkan dengan model Business Intelligence (BI) yang dapat menghasilkan informasi absensi dalam bentuk visualisasi operasional dashboard.

\section{UCAPAN TERIMA KASIH}

Terimakasih saya ucapkan untuk civitas SMP Negeri 29 Pekanbaru atas kesempatannya untuk dijadikan studi kasus penelitian ini. Terimakasih kepada Politeknik Caltex Riau dan Ibu Shumaya Resty Ramadhani selaku pembimbing yang telah mendukung dan membantu penelitian saya hingga selesai.

\section{DAFTAR PUSTAKA}

[1] L. M. M. Rani, H. Elmunsyah, and Muladi, "Pengembangan Media Pembelajaran Berbasis Content Management System (CMS) Yang Diintegrasikan Dengan Media Sosial Pada Mata Pelajaran Produktif TKJ Kelas X SMKN 1 Pungging, Mojokerto," J. Teknol. Elektro dan Kejuru., vol. 24, no. September, pp. 15-22, 2015.

[2] Y. W. A. Rustam, "Perancangan Aplikasi Mobile Untuk Pemasaran Produk dan Jasa ke Berbagai Situs E-Commerce di Indonesia," J. Inf., vol. VI, no. 2, pp. 88-99, 2017.

[3] Trisnani, "Pemanfaatan Whatsapp Sebagai Media Komunikasi dan WhatsApp Utilization As Media Communication and Satisfaction In Submission of Messages among People of the Community," J. Komun. media dan Inform., 2017.

[4] M. Yusmita, Z. Larisu, and Saidin, "Pemanfaatan Whatsapp Messenger Sebagai Media Komunikasi Antar Pribadi
Mahasiswa Ilmu Komunikasi *Mei Yusmita ** Dr. Zulfiah Larisu, S.Sos, M.Si., *** Saidin, S.Ip, M.Si.,” pp. 1-12, 2014.

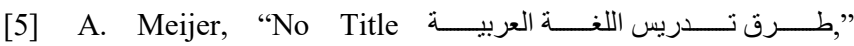
Экономика Региона, vol. 2012, no. August, p. 32, 2013.

[6] A. Triwahyuni, "Sistem Informasi Absensi Siswa ( Studi Kasus Perguruan Islam Mathali ' Ul Falah Pati Jawa Tengah )," vol. 2, no. 3, pp. 249-256, 2012.

[7] A. Ilmiah, "Sistem Informasi Manajemen Nilai dan Absensi SMP Negeri 4 Salatiga," no. 702011041, 2017.

[8] D. E. Kurniawan and A. Fatulloh, 'Attendance Management System Using Fingerprint Scanner in Central Network', 2019.

[9] P. Studi, S. Informasi, and P. C. Riau, "Implementasi Sistem Rekapitulasi Hasil Pembelajaran dan Absensi Berbasis Web dengan Framework CodeIgniter ( CI ) ( Studi Kasus : SMA 2 Tualang) Implementasi Sistem Rekapitulasi Hasil Pembelajaran dan Absensi Berbasis Web dengan Framework CodeIgniter ( CI," no. Ci, 2017.

[10] D. E. Kurniawan, N. Z. Janah, A. Wibowo, M. K. Mufida, and P. Prasetyawan, 'C2C marketplace model in fishery product trading application using SMS gateway', MATEC Web Conf., vol. 197, 2018.

[11] C. Jienardy, "Gap Analisis Persepsi Dan Ekspektasi Konsumen," J. Manaj. dan Start-Up Bisnis, vol. 1, 2017.

[12] R. Nugraha, H. Ambar, and H. Adianto, "Usulan Peningkatan Kualitas Pelayanan Jasa pada Bengkel ' $\mathrm{X}$ ' Berdasarkan Hasil Matrix Importance-Performance Analysis (Studi kasus di Bengkel AHASS PD. Sumber Motor Karawang)," J. Online Inst. Teknol. Nas., vol. 1, no. 3, pp. 221-231, 2014, doi: $2338-5081$

[13] T. S. Jaya, "Pengujian Aplikasi dengan Metode Blackbox Testing Boundary Value Analysis," J. Inform. J. Pengemb. IT Poltek Tegal, 2018, doi: 10.30591/jpit.v3i1.647. 